\title{
Highly Promiscuous Oxidases Discovered in the Bovine Rumen Microbiome
}

\begin{abstract}
Lisa Ufarté1, Gabrielle Potocki-Veronese', Davide Cecchini', Alexandra S. Tauzin', Angeline Rizzo', Diego P. Morgavi², Bernard Cathala ${ }^{3}$, Céline Moreau ${ }^{3}$, Megane Cleret ${ }^{1}$, Patrick Robe ${ }^{4}$, Christophe Klopp ${ }^{5}$ and Elisabeth Laville ${ }^{1 *}$
\end{abstract}

\begin{abstract}
1 Laboratoire d'Ingénierie des Systèmes Biologiques et des Procédés, Centre National de la Recherche Scientifique, Institut National de la Recherche Agronomique, Institut National des Sciences Appliquées de Toulouse, Université de Toulouse, Toulouse, France, ${ }^{2}$ INRA, UMR 1213 Herbivores, Saint-Genès Champanelle, France, ${ }^{3}$ UR1268 Biopolymères Interactions Assemblages, INRA, Nantes, France, ${ }^{4}$ LibraGen S.A, Toulouse, France, ${ }^{5}$ Plateforme Bio-informatique Toulouse Genopole, UBIA INRA, BP 52627, Castanet-Tolosan, France
\end{abstract}

The bovine rumen hosts a diverse microbiota, which is highly specialized in the degradation of lignocellulose. Ruminal bacteria, in particular, are well equipped to deconstruct plant cell wall polysaccharides. Nevertheless, their potential role in the breakdown of the lignin network has never been investigated. In this study, we used functional metagenomics to identify bacterial redox enzymes acting on polyaromatic compounds. A new methodology was developed to explore the potential of uncultured microbes to degrade lignin derivatives, namely kraft lignin and lignosulfonate. From a fosmid library covering 0.7 Gb of metagenomic DNA, three hit clones were identified, producing enzymes able to oxidize a wide variety of polyaromatic compounds without the need for the addition of copper, manganese, or mediators. These promiscuous redox enzymes could thus be of potential interest both in plant biomass refining and dye remediation. The enzymes were derived from uncultured Clostridia, and belong to complex gene clusters involving proteins of different functional types, including hemicellulases, which likely work in synergy to produce substrate degradation.

\footnotetext{
Keywords: bovine rumen, microbiome, functional metagenomics, lignin degradation, redox enzymes, biorefining, dye bioremediation
}

\section{INTRODUCTION}

Oxidoreductases are a large family of enzymes - including laccases, alcohol oxidases, monooxygenases, mono- and oligosaccharide oxidases, lignin peroxidases, cytochrome C oxidases, NADPH oxidases, and monoamine oxidases - that catalyze oxidation-reduction (redox) reactions, and which have a broad variety of substrate specificities and reaction mechanisms. Several oxidoreductase enzymes are already being used in industrial applications, such as dye decolorization, soil and water bioremediation, and biorefining. For decades, most of our understanding of aromatic compound-degrading microorganisms has come from functional genomics or studying model microbial communities (Pieper et al., 2004). However, most of the microorganisms capable of breaking down aromatic compounds remain uncharacterized as a result of our inability to isolate and culture them. This is why the search for novelty remains a challenge. Functional metagenomics is a highly efficient tool in the search for novel biocatalysts among 
the huge diversity of uncultured microbes. Several metagenomic studies performed on microbial communities derived from polluted environments have led to the identification of new oxygenases involved in the degradation of aromatic compounds, which could have potential applications for bioremediation (for a review, see Ufarté et al., 2015). In 2005, Ferrer et al. (2005) discovered a polyphenol oxidase with laccase activity derived from a bovine rumen metagenome, which was the first functionally characterized member of this new enzyme family (Beloqui et al., 2006). While this study proved that redox enzymes acting on polyaromatic compounds can be retrieved from uncultured ruminal bacteria, this particular enzyme and its homologs have never been tested on lignin or its derivatives. In fact, examples of ecosystems that have been screened in order to identify enzymes involved in the degradation of lignin or lignin-derived products are scarce. A bacterial laccase acting on guaiacol, a product of lignin combustion, was first discovered while conducting activity-based screening of a metagenome sampled from mangrove soil (Ye et al., 2010). In addition, a pseudo-laccase requiring the use of exogenous $\mathrm{Cu}$ (II) for oxidase activity was retrieved from a coal bed metagenome being screened for lignin catabolic activity (Strachan et al., 2014). Recently, a laccase isolated from acidic bog peat using a PCR-based method was characterized and showed specificity for phenolic substrates that could be linked to lignin degradation (Ausec et al., 2017). These pioneering studies highlight the promiscuity of many oxidoreductases toward this kind of substrate, and the metagenome flexibility in loci encoding polyaromatic degrading pathways. However, the main obstacle to their discovery and characterization is the lack of experimental screens of redox enzymes, which would allow the exploration of a sufficiently large sequence space to permit such rare enzymes to be identified. This is especially true for those enzymes acting in anaerobic or microaerobic conditions, whose potential for discovery using activity-based approaches is limited (Brown and Chang, 2014). It is worth noting that such enzymes are probably very rare in certain ecosystems. For example, no laccase sequence could be found in the cow rumen metagenome studied by Ausec et al. (2011).

In rumens, lignin is present in the form of dietary plant cell wall constituents and is known to be partly degraded by anaerobic fungi and bacteria (Ruiz-Dueñas and Martínez, 2009; Abrão et al., 2017; Baba et al., 2017). One of the reasons for this could be that lignin degradation is an oxidative process, which has been described mostly with reference to aerobic ecosystems where di-oxygen can act as an electron acceptor. Due to their relative low abundance, lignin-degrading bacteria remain hard to detect and further research is thus needed to deepen our understanding of the different lignin degradation mechanisms that occur in the bovine gastrointestinal tract.

As part of this research, we used functional metagenomics to identify novel redox enzymes from uncultured ruminal bacteria. We describe a new strategy comprising three main steps that combines standard redox reactions with two innovative methods to extend the characterization of hit clones. Primary screening was performed on model substrates for redox reactions, allowing the retrieval of three isolated hit clones. Thereafter, the hit clones were used in a newly developed screening method based on colored semi-reflective films to determine their ability to depolymerize lignin derivatives. Their potential to eliminate industrial dyes was then investigated by testing their ability to degrade a panel of aromatic dyes on solid or liquid media. Finally, the sequences of the hit clones were annotated, permitting the genes involved in the catabolism of aromatic compounds, including lignin derivatives, to be identified.

\section{MATERIALS AND METHODS}

\section{Chemicals}

The reagents used in this study were: lignin alkali (kraft lignin), 2,2'-azino-bis (3-ethylbenzothiazoline-6-sulfonic acid) diammonium salt (ABTS), 1-hydroxybenzotriazole (1-HBT), the free radical 2,2,6,6-tetramethyl-1-piperidinyloxy (TEMPO), and 3',5'-dimethoxy-4'-hydroxyacetophenone (acetosyringone and 3,5-dimethoxy-4-hydroxybenzaldehyde (syringaldehyde) purchased from Sigma-Aldrich (France). The dyes used were: acid fuschin (AF), amaranth (A), and tropaeolin O (TO) purchased from Fisher Scientific (France); and reactive orange 16 (RO16), malachite green ( $\mathrm{MG})$, cibracon brillant red 3BA (CBR3BA), reactive black 5 (RB5), and remazol brilliant blue $\mathrm{R}$ (RBBR) purchased from Sigma-Aldrich (France). The structure of these dyes is summarized in Table $\mathbf{1}$.

The chemicals used to produce the semi-reflective layers were: melamine-formaldehyde (MF) resin (Madurit 75\%, MW 112) supplied by INEOS Melamines GmbH (Frankfurt, Germany), lignosulfonate supplied by Tembec (Montréal, Canada), xyloglucan (XG) from Tamarindus indica supplied by Megazyme (Bray, County Wicklow, Ireland; $M_{\mathrm{w}}=202 \mathrm{kD}$; viscosity: $6.5 \mathrm{dL} / \mathrm{g}$; sugar composition: xylose $=38 \%$, glucose $=42 \%$, galactose $=16 \%$, arabinose $=4 \%$ ) and poly(allylamine hydrochloride) (PAH; $\left.M_{\mathrm{w}}=120,000-200,000 \mathrm{~g} / \mathrm{mol}\right)$ supplied by PolySciences (Germany).

\section{Metagenomic DNA Sampling and Library Construction}

Rumen contents were obtained from two non-producing rumencannulated Holstein dairy cows. They were reared according to the national standards established by French legislation on animal care (Certificate of Authorization to Experiment on Living Animals, No. 004495, Ministry of Agriculture, France) at the Herbipole experimental unit (INRA, Theix). The experiments that form part of this study were approved by the Auvergne Regional Ethical committee for animal experimentation (No. $11 / 01438$ ). Before sampling, the cows' diet was altered for a period of 7 weeks to consist of $80 \%$ wheat straw, $12 \%$ concentrate, and $8 \%$ beetroot molasses. They were fed ad libitum once a day in the morning. Rumen contents were taken before feeding from various parts of the rumen and manually homogenized.

Enriched bacterial fractions were recovered separately from the two rumen samples which had been thawed at room temperature by applying a density gradient technique using Nycodenz such as has been described elsewhere (see Courtois et al., 2003). The cell pellets from both cows were suspended in 
TABLE 1 | Structures of the tested dyes ( $A Z O=$ azo dye; $A=$ anthraquinonic dye; $T$ = triarylmethane dye), and their maximum absorbance wavelength.

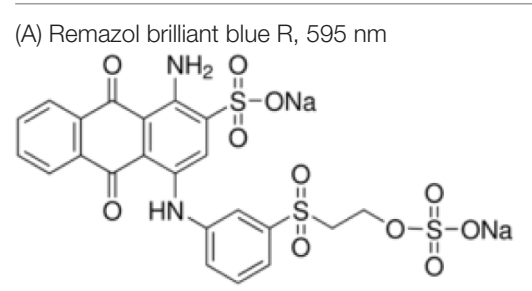

(AZO) Cibracon brilliant red 3BA, $525 \mathrm{~nm}$<smiles>O=C(Nc1cc(S(=O)(=O)O[Na])cc2cc(S(=O)(=O)O)c(O)c(N=Nc3cc(Nc4nc(Cl)nc(Nc5ccc(S(=O)(=O)O)cc5)n4)ccc3S(=O)(=O)O)c12)c1ccccc1</smiles>

(AZO) Tropaeolin O, 390 nm

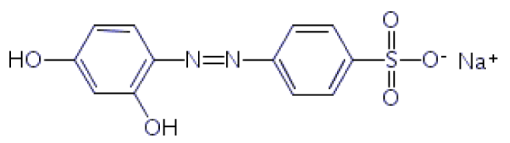

(T) Acid fuchsin, $545 \mathrm{~nm}$<smiles>Cc1cc(C(=C2C=CC(=N)C(S(=O)(=O)O)=C2)c2ccc(N)c(S(=O)(=O)O)c2)cc(S(=O)(=O)O)c1N</smiles>

(AZO) Reactive orange 16, 385-495 nm<smiles>CC(=O)Nc1ccc2cc(S(=O)(=O)O)c(N=Nc3ccc(S(=O)(=O)CCOS(=O)(=O)O)cc3)c(O)c2c1</smiles>

(AZO) Reactive black 5, $600 \mathrm{~nm}$

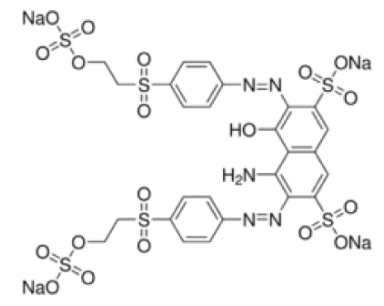

(AZO) Amaranth, $520 \mathrm{~nm}$<smiles>NS(=O)(=O)c1ccc2c(N=Nc3ccc(S(=O)(=O)O[Na])c4ccccc34)c(O)c(S(=O)(=O)O[Na])cc2c1</smiles>

(T) Malachite green, 425-620 nm<smiles>CN(C)c1ccc(C(=C2C=CC([N+](C)C)C=C2)c2ccccc2)cc1</smiles>

a buffer comprised of equal parts by weight of $50 \mathrm{mM}$ Tris ( $\mathrm{pH} 8$ ) and $100 \mathrm{mM}$ EDTA, and then incorporated into low-melt-point agarose before a gentle enzymatic lysis took place, as has also been described elsewhere (see Tasse et al., 2010). Fragments sizing between 30 and $40 \mathrm{~kb}$ were isolated and cloned into a pCC1FOS fosmid (Epicenter Technologies). EPI100 Escherichia coli cells were then transfected to obtain a library of 19,968 clones from the rumen samples. Recombinant clones were transferred to 384well microtiter plates containing a Luria-Bertani (LB) medium, supplemented with $12.5 \mathrm{mg} / \mathrm{L}$ chloramphenicol and $8 \%(\mathrm{w} / \mathrm{v})$ glycerol. They were grown for a period of $22 \mathrm{~h}$ at $37^{\circ} \mathrm{C}$ and then frozen and conserved at $-80^{\circ} \mathrm{C}$. All other culture media mentioned in this study contained $12.5 \mathrm{mg} / \mathrm{L}$ chloramphenicol.

\section{Metagenomic Library Screening}

A fresh copy of the library's 19,968 clones was gridded on $22 \mathrm{~cm} \times 22 \mathrm{~cm}$ trays containing a solid agar medium, using an automated microplate gridder (K2, KBiosystems, Basildon,
United Kingdom). A solid agar minimal medium containing $1 \%$ filter sterilized lignin alkali $(\mathrm{w} / \mathrm{v})$ as the sole carbon source was used. The minimal medium was composed of salts $(3.6 \mathrm{~g} / \mathrm{L}$ $\mathrm{Na}_{2} \mathrm{HPO}_{4}, \mathrm{H}_{2} \mathrm{O} ; 0.62 \mathrm{~g} / \mathrm{L} \mathrm{KH}_{2} \mathrm{PO}_{4} ; 0.11 \mathrm{~g} / \mathrm{L} \mathrm{NaCl} ; 0.42 \mathrm{~g} / \mathrm{L}$ $\left.\mathrm{NH}_{4} \mathrm{Cl}\right), 0.49 \mathrm{~g} / \mathrm{L} \mathrm{MgSO} 4,4.38 \mathrm{mg} / \mathrm{L} \mathrm{CaCl}_{2}$, other salts $(15 \mathrm{mg} / \mathrm{L}$ $\mathrm{Na}_{2}$ EDTA, $2 \mathrm{H}_{2} \mathrm{O} ; 4.5 \mathrm{mg} / \mathrm{L} \mathrm{ZnSO} 4,7 \mathrm{H}_{2} \mathrm{O} ; 0.3 \mathrm{mg} / \mathrm{L} \mathrm{CoCl}$, $6 \mathrm{H}_{2} \mathrm{O} ; 1 \mathrm{mg} / \mathrm{L} \quad \mathrm{MnCl}_{2}, 4 \mathrm{H}_{2} \mathrm{O} ; 1 \mathrm{mg} / \mathrm{L} \quad \mathrm{H}_{3} \mathrm{BO}_{3} ; 0.4 \mathrm{mg} / \mathrm{L}$ $\mathrm{Na}_{2} \mathrm{MoO}_{4}, 2 \mathrm{H}_{2} \mathrm{O} ; 3 \mathrm{mg} / \mathrm{L} \mathrm{FeSO}, 7 \mathrm{H}_{2} \mathrm{O} ; 0.3 \mathrm{mg} / \mathrm{L} \mathrm{CuSO}$, $5 \mathrm{H}_{2} \mathrm{O}$ ), $0.04 \mathrm{~g} / \mathrm{L}$ leucine, and $0.1 \mathrm{~g} / \mathrm{L}$ thiamine hypochloride. The assay plates were incubated at $37^{\circ} \mathrm{C}$ for a period of between 1 and 3 weeks, depending on the time needed to visualize the growth of the hit clones.

\section{Functional Characterization of the Hit Clones}

The hit clones isolated after primary screening due to their growth on lignin alkali as the sole carbon source were then assayed to determine the optimal conditions of ABTS oxidation 
and were further examined for their activity on different aromatic compounds, these being: (1) sulfonated lignin films, (2) mediators, which are model substrates used to assess oxidoreductase activity, and (3) dyes. The hit clones were grown at $37^{\circ} \mathrm{C}$ in $20 \mathrm{~mL} \mathrm{LB}$ medium, with orbital shaking at $120 \mathrm{rpm}$. After $16 \mathrm{~h}$, cells were harvested using centrifugation for $5 \mathrm{~min}$ at 5,000 rpm, before being re-suspended and concentrated in an activity buffer ( $10 \mathrm{mM}$ sodium citrate buffer adjusted to optimal pHs as determined below) to obtain a final $\mathrm{OD}_{600 \mathrm{~nm}}$ of 80. Cell lysis was carried out using sonication. Cell debris was centrifuged at $13,000 \mathrm{rpm}$ for $10 \mathrm{~min}$ and the cytoplasmic extracts were filtered using a $0.20 \mu \mathrm{m}$ Minisart RC4 Syringe Filter.

Due to the potential for E. coli to degrade some aromatic compounds (Diaz et al., 2001; Solís et al., 2012), an E. coli EPI100 clone containing the pCC1FOS fosmid but without a metagenomic DNA fragment was used as a negative control.

Each experiment was carried out at least twice, and means are reported in the figures and tables included in this paper.

\section{Determination of Optimal Reaction Conditions}

Enzymatic reactions were carried out in 96-well microtiter plate assays using ABTS as a reductive chromogenic substrate. Each well contained $200 \mu \mathrm{L}$ of the reaction medium: $20 \mu \mathrm{L}$ of cytoplasmic extract, $5 \mathrm{mM}$ ABTS, and $100 \mathrm{mM}$ of a sodium citrate buffer at the optimal pHs. ABTS oxydation was determined by monitoring absorbance at $420 \mathrm{~nm}$ using a microplate spectrophotometer BioTek $^{\mathrm{TM}}$ Eon $^{\mathrm{TM}}$ Microplate Spectrophotometers, Colmar, France). The activity of ABTS oxidation was expressed in $\mu \mathrm{mol} / \mathrm{min} / \mathrm{L}$ of culture, using the extinction coefficient value $\varepsilon$ ABTS $(420 \mathrm{~nm})=36,000 \mathrm{M}^{-1} \cdot \mathrm{cm}^{-1}$.

First, we determined optimal $\mathrm{pH}$ at $30^{\circ} \mathrm{C}$ in $100 \mathrm{mM}$ sodium citrate buffer supplemented with $10 \mathrm{mM} \mathrm{CuSO}_{4}$, by monitoring absorbance at $420 \mathrm{~nm}$ over a period of $30 \mathrm{~min}$ for $\mathrm{pHs} 4.0$, $4.5,5.0,5.5$, and 6.0. Then, we determined the effect of $\mathrm{CuSO}_{4}$ concentration at $30^{\circ} \mathrm{C}$ and optimal $\mathrm{pH}$ by monitoring absorbance at $420 \mathrm{~nm}$ over a period of $30 \mathrm{~min}$ for $0,0.1,1$, and $10 \mathrm{mM} \mathrm{CuSO}_{4}$. Finally, optimal temperature was determined at optimal $\mathrm{pH}$ by monitoring absorbance at $420 \mathrm{~nm}$ over a period of $30 \mathrm{~min}$ at temperatures of $22,30,37,40,50$, and $60^{\circ} \mathrm{C}$.

Thermal stability was determined at the hit clones' optimal pHs and temperatures by monitoring absorbance at $420 \mathrm{~nm}$ after $30 \mathrm{~min}$ of incubation. The optimal temperature for longterm reactions was determined at optimal $\mathrm{pH}$ by end-point measurement of absorbance after $17 \mathrm{~h}$ of reaction at $22,30,37$, 40,50 , and $60^{\circ} \mathrm{C}$. All the reactions in this study were carried out in 96-well microplates containing $200 \mu \mathrm{L}$ of reaction medium. In order to limit evaporation, particularly for long reaction times, the microplates were covered with a lid and placed in a closed chamber saturated with moisture. The effect of $\mathrm{H}_{2} \mathrm{O}_{2}$ was tested at optimal $\mathrm{pH}$ and temperature by adding $3 \%(\mathrm{v} / \mathrm{v})$ of $\mathrm{H}_{2} \mathrm{O}_{2}$ to the reaction medium.

\section{Enzymatic Activity on Mediators}

The optimal conditions for long-term reactions when using ABTS as a substrate were used to measure the activity of the three clones on different mediators. The final concentrations of substrates in the $100 \mathrm{mM}$ sodium citrate buffer at the optimal pHs were $18 \mathrm{mM}$ of 1 -HBT and $2 \mathrm{mM}$ of acetosyringone, TEMPO, and syringaldehyde; with $20 \mu \mathrm{L}$ of cytoplasmic extract, for a total reaction volume of $200 \mu \mathrm{L}$. To allow substrates to be more easily compared, activity was expressed as UOD/min/L (where UOD stands for units of optical density) of culture after spectrophotometric observation at 408,528, 300, and $370 \mathrm{~nm}$, respectively. Background activity was determined under the same conditions for the biotic negative control.

\section{Degradation of Semi-reflective Layers of Sulfonated Lignin}

An anchoring solution of $4 \mathrm{~g} / \mathrm{L}$ PAH was deposited on a silicon wafer, allowed to adsorb for $5 \mathrm{~min}$, and then the support was spin-coated at 3,500 rpm for $1 \mathrm{~min}$ with an acceleration of 1,400 rpm/s. The MF resin mix (10\% stock solution), along with lignosulfonate (100 g/L lignin stock solution, $75 \mathrm{~g} / \mathrm{L}$ final) or tamarind xyloglucan (20 g/L stock solution, $10 \mathrm{~g} / \mathrm{L}$ final), was deposited onto the wafer and spin-coated at 1,500 rpm for $3 \mathrm{~min}$ with an acceleration of $100 \mathrm{rpm} / \mathrm{s}$. The films were put in an oven for $35 \mathrm{~min}$ at $135^{\circ} \mathrm{C}$, then left to cool down to ambient temperature. The films were then washed in ultra-pure water for $2 \mathrm{~h}$ to shake off unfixed residues. Two microliters of cellular extracts was deposited on the films and incubated at the optimal temperature for $3 \mathrm{~h}$ in a saturated humidity atmosphere. The films were then washed with ultra-pure water and dried before observation.

\section{HPAEC-PAD Analysis}

The hydrolytic activity of Clone 1 on tamarind xyloglucan was examined using HPAEC-PAD. Enzymatic reactions were carried out at $37^{\circ} \mathrm{C}$ by adding $100 \mu \mathrm{L}$ of xyloglucan solution $(5 \mathrm{mg} / \mathrm{mL}$ final concentration) to $100 \mu \mathrm{L}$ of cytoplasmic extract from the hit clone. After $24 \mathrm{~h}$ incubation, the samples were diluted by a factor of 10 with MilliQ water and analyzed using HPAEC-PAD on a Dionex ICS-3000 System (Dionex) equipped with a CarboPac PA100 column. The analyses were carried out at $30^{\circ} \mathrm{C}$ with a flow rate of $0.25 \mathrm{~mL} / \mathrm{min}$ and the following multi-step gradient: $0-30 \mathrm{~min}(0-60 \% \mathrm{~B}), 30-31 \mathrm{~min}(60-0 \% \mathrm{~B})$, and $31-36 \mathrm{~min}$ $(0 \% \mathrm{~B})$. The solvents used were $150 \mathrm{mM} \mathrm{NaOH}$ (eluent A) and $150 \mathrm{mM} \mathrm{NaOH}$, and $500 \mathrm{mM} \mathrm{CH} 3 \mathrm{COONa}$ (eluent B). The EPI100 E. coli strain harboring the empty pCC1FOS vector was used as a control. It was not able to degrade xyloglucan under the same conditions.

\section{Dye Discoloration Assays}

\section{Selective growth on solid media with dyes as the sole carbon source}

The dye decolorizing activity of clones was first screened on agar plates containing agar with a minimal medium (composition above), $1 \mathrm{mM} \mathrm{CuSO}_{4}$, and $70 \mathrm{ppm}$ of dyes as the sole carbon source (excluding the agar itself) in a sodium citrate buffer (100 mM final concentration) at the optimal pHs determined for the three clones. The plates were inoculated with the hit clones as well as the E. coli EPI100 control, and incubated at $37^{\circ} \mathrm{C}$ for a period of 5 days. 


\section{Discoloration of liquid reaction media}

The optimal conditions determined for long-term reactions were used to quantify dye discoloration in liquid media. The experiment was carried out over a period of $72 \mathrm{~h}$, in 96-well microtiter plates containing a final concentration of $70 \mathrm{ppm}$ of dye dissolved in $100 \mathrm{mM}$ sodium citrate buffered at the optimal pHs, and $20 \mu \mathrm{L}$ of cellular extract, for a final volume of $200 \mu \mathrm{L}$. The reaction media were centrifuged at $3,700 \mathrm{rpm}$ for $10 \mathrm{~min}$. The absorbance spectrum of each supernatant was measured using a microplate spectrophotometer $\left(B^{1}\right.$ Tek $^{\mathrm{TM}}$ Eon $^{\mathrm{TM}}$ Microplate Spectrophotometers, Colmar, France) at the initial and final reaction times. The dye discoloration yield was calculated using the decrease in absorbance at the wavelength of maximum absorbance, determined for each dye between the initial and final reaction times as follows: discoloration $(\%)=\left(\left[\left(A_{0}-A_{72}\right) / A_{72}\right]\right.$

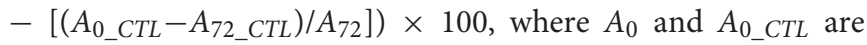
the initial absorbance of the dye in the cellular extract of the metagenomic clone and the E. coli control, respectively, at initial reaction time; and $A_{72}$ and $A_{72}$ CTL are the absorbance of the dye in the cellular extract of the metagenomic clones and the E. coli control, respectively, after the reaction had taken place (Phugare et al., 2011). The spectra for the RO16 and MG dyes produced two $\lambda_{\max }$ values, both of which are reported in the "Results" section.

\section{Metagenomic Sequence Analysis}

The fosmid DNA of the clone hits was extracted using the NucleoBond Xtra Midi kit from Macherey-Nagel (France) on the recommendation of the supplier. Fosmids were then sequenced using the MiSeq System (Illumina) at the GeT-PlaGe Genomics Platform (Auzeville, France). Read assembly was performed using Masurca ${ }^{1}$. The contigs were cleaned from the pCC1FOS vector sequence using Crossmatch ${ }^{2}$. The three annotated contig sequences were deposited in the DDBJ/ENA/GenBank Nucleotide Sequence Database under accession numbers LT674548, LT674550, and LT674549. Open-reading frames (ORFs) of at least 20 amino acids were predicted using MetaGene (Noguchi et al., 2006). ORF functions were inferred based on BLASTX analysis against the NCBI non-redundant and environmental databases ( $e$-value $<10^{-8}$, identity $>35 \%$, and query length coverage $\geq 50 \%$ ). The ORFs were assigned to clusters of orthologous groups of proteins (COGs) using RPSBLAST analysis against the COG database $\left(e\right.$-values $\left.\leq 10^{-8}\right)$. A comparison was performed using BLASTP analysis against the Laccase and multicopper oxidase engineering database (LccED) $\left(e\right.$-value $<10^{-8}$, identity $\geq 20 \%$, and query length coverage $\geq 20 \%$ ) (Sirim et al., 2011). The protein signatures were detected using the InterProScan web service ${ }^{3}$ (Jones et al., 2014).

Contig taxonomic assignment was carried out using MEGAN v5.10.6 (Huson et al., 2011), based on BLASTX analysis against the non-redundant NCBI database $(\mathrm{min}$. score $=35, \mathrm{~min}$. support $=1$ ). Contigs were assigned to a class, genus, or species only if at least $50 \%$ of the ORFs were assigned to the same organism.

\footnotetext{
${ }^{1}$ http://www.genome.umd.edu/masurca.html

${ }^{2}$ http://bozeman.mbt.washington.edu/phredphrapconsed.html

${ }^{3}$ http://www.ebi.ac.uk/interpro/
}

\section{RESULTS AND DISCUSSION}

\section{Metagenomic Library Screening}

The library consisted of 19,968 E. coli fosmid clones, covering in total $0.7 \mathrm{Gbp}$ of the metagenomic DNA from the rumen bacteria, with each clone containing a 30-40 kb DNA insert. The library was first screened for the ability to metabolize a depolymerized product of native lignin, namely lignin alkali, used as the sole carbon source for metagenomic clone growth. Lignin alkali, or kraft lignin, is the main by-product produced during the alkaline sulfide treatment of lignocelluloses in the pulp and paper industry. A minimal medium with kraft lignin such as this has already been used to isolate strains able to degrade this substrate (Raj et al., 2007). However, this screen has never been used to identify enzymes from metagenomic libraries, in which each clone only contains a small fraction of the genome from the native bacterium, limiting its substrate harvesting and metabolic potential. The functional assay carried out as part of this study allowed three clones to be identified that were able to grow in a mineral medium with kraft lignin as a the sole carbon source. The hit frequency was $0.015 \%$. This is a value comparable to the hit yield found for oxidase screening in the rumen ecosystem $(0.007 \%$ in Beloqui et al., 2006), although the latter was not specific to the degradation of lignin-related products. In contrast, the hit frequency was lower than that obtained from environments contaminated with polyaromatic compounds, such as activated sludge $(0.09 \%$ in Suenaga et al., 2007) and oil-contaminated waters $(0.2 \%$ in de Vasconcellos et al., 2010 and 3\% in Silva et al., 2013).

\section{Characterization of Redox Activity Determination of Optimal Reaction Conditions}

The enzymatic characterization of the metagenomic clones allowed enzyme stability to be assessed, as well as the enzymes' versatility and efficiency toward structurally different substrates, i.e., mediators and dyes. All the assays were performed using cell extracts, which contained both the recombinant enzymes, and molecules from the cellular metabolism of E. coli such as ions, cofactors, and even enzymes. In order to characterize the substrate specificity of the three clones, optimal conditions of activity were determined by monitoring the oxidation of ABTS at various $\mathrm{pHs}$ and temperatures (Table 2). All clones displayed optimal activity at acidic $\mathrm{pH}$ values, optimal $\mathrm{pH}$ being 4.5 for Clones 1 and 3, and 5.0 for Clone 2. Oxidative activity was totally lost when the $\mathrm{pH}$ value was higher than 6.0 (Clones 1 and 3), and with Clone 2 it was lost after the $\mathrm{pH}$ reached 5.5 (Figure 1A). The optimal temperature was $60^{\circ} \mathrm{C}$ for Clones 1 and 3 , and $50^{\circ} \mathrm{C}$ for Clone 2 (Figure 1B). However, after $30 \mathrm{~min}$ at their optimal temperatures, only 13,11 , and $31 \%$ of activity remained for Clones 1, 2, and 3, respectively, indicating a moderate thermal stability for the enzymatic extracts. The optimal reaction temperature was thus determined according to the stability of the extracts over a $17 \mathrm{~h}$ incubation period. Optimal reaction temperatures were found to be $50^{\circ} \mathrm{C}$ for Clones 1 and 3 , and $30^{\circ} \mathrm{C}$ for Clone 2 (Figure 1C). 
TABLE 2 | Optimal conditions for ABTS oxidation for the hit metagenomic clones.

\begin{tabular}{lccc}
\hline Optimal conditions & Clone 1 & Clone 2 & Clone 3 \\
\hline $\mathrm{pH}$ & 4.5 & 5.0 & 4.5 \\
Temperature $\left({ }^{\circ} \mathrm{C}\right)$ & 60 & 50 & 60 \\
Temperature for long-term reactions $\left({ }^{\circ} \mathrm{C}\right)$ & 50 & 30 & 50
\end{tabular}

The oxidative enzymes of Clones 1, 2, and 3 were not laccases or peroxidases: the addition of a copper metal or hydrogen peroxide ion to the reaction media had no significant effect on the reaction rate of the clones.

\section{Enzymatic Activity on Model Substrates}

Using optimal reaction conditions (Table 2), substrate specificity was characterized by comparing the activity of the cell extracts on five mediators whose structure and redox potential were known: ABTS, TEMPO, HBT, acetosyringone, and syringaldehyde. Syringaldehyde and acetosyringone are phenolic compounds, and are two of the main products of the degradation of syringylrich lignins. They are characterized by the presence of two methoxy substituents in ortho positions of the phenol, which lowers their redox potential. They have stable radicals, since the substituents have a steric hindrance effect on polymerization due to radical fusion. The TEMPO molecule is a stable radical characterized by a nitroxyl group that benefits from the steric protection provided by the four methyl groups adjacent to the nitroxyl group $\mathrm{N}-\mathrm{O}_{2}$. The methyl groups prevent a double bond occurring between carbons adjacent to nitrogen. ABTS contains two sulfonate groups that can be deprotonated. The HBT substrate is characterized by an $\mathrm{N}-\mathrm{OH}$ group for which enzymatic oxidation is mediated by the formation of the highly active nitroxyl radical $>\mathrm{N}-\mathrm{O}^{\bullet}$, caused by the removal of an electron followed by the release of a proton (Camarero et al., 2005; Morozova et al., 2007; Tavares et al., 2008; Torres-Duarte et al., 2009; Pardo et al., 2013).

Clone 1 was active on all substrates and displayed the highest activity compared to the other two clones (Figure 2). Clone 2 displayed low levels of activity on all substrates, although activity was nevertheless detectable on all substrates, especially TEMPO. Clone 3 was the most significantly active on acetosyringone and syringaldehyde. Overall, the three clones exhibited a considerable degree of flexibility toward structurally different substrates, with Clones 1 and 3 demonstrating the highest efficiency. Figure 2 shows the background noise for E. coli, confirming that it has the enzymatic machinery for oxidation. This background noise varied depending on the mediator, and also on whether Clone 2 or Clones 1 and 3 were being tested, due to differences in reaction conditions (Table 2).

\section{Lignin-Derivative Depolymerization}

The results of the primary screening indicated the presence of ruminal bacterial oxidoreductases, which may be involved in lignin degradation. Nevertheless, at this stage, we had not found evidence of their ability to break down polymeric lignin. We thus developed a depolymerization screening strategy, using colored semi-reflective films of polymeric sulfonated lignin

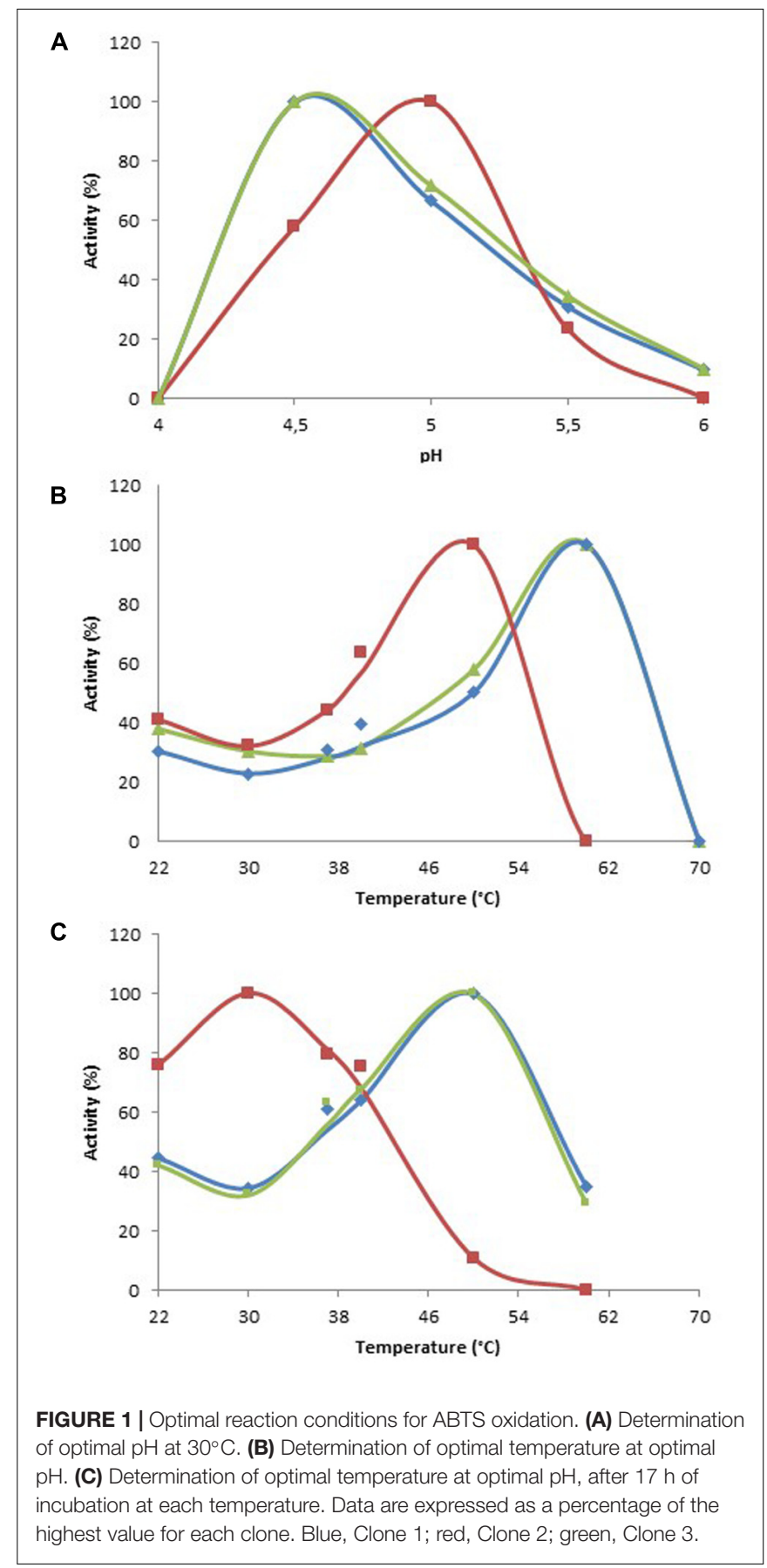

(Cerclier et al., 2011), which is a by-product of the chemical pulping process (Lebo et al., 2001). As is the case with butterfly wings, the principle of this method is based on structural colors; that is, colors arising from light interference and not the presence of dyes. Modulation of the color of the semi-reflective nano-layers of polymer depends on film thickness and the refractive index of the final film. Incident light hits the air-film interface, where part of it is reflected back while the rest is transmitted into the film. The second reflection occurs at the film-substrate interface. Net reflected light intensity depends on the combination of reflected 


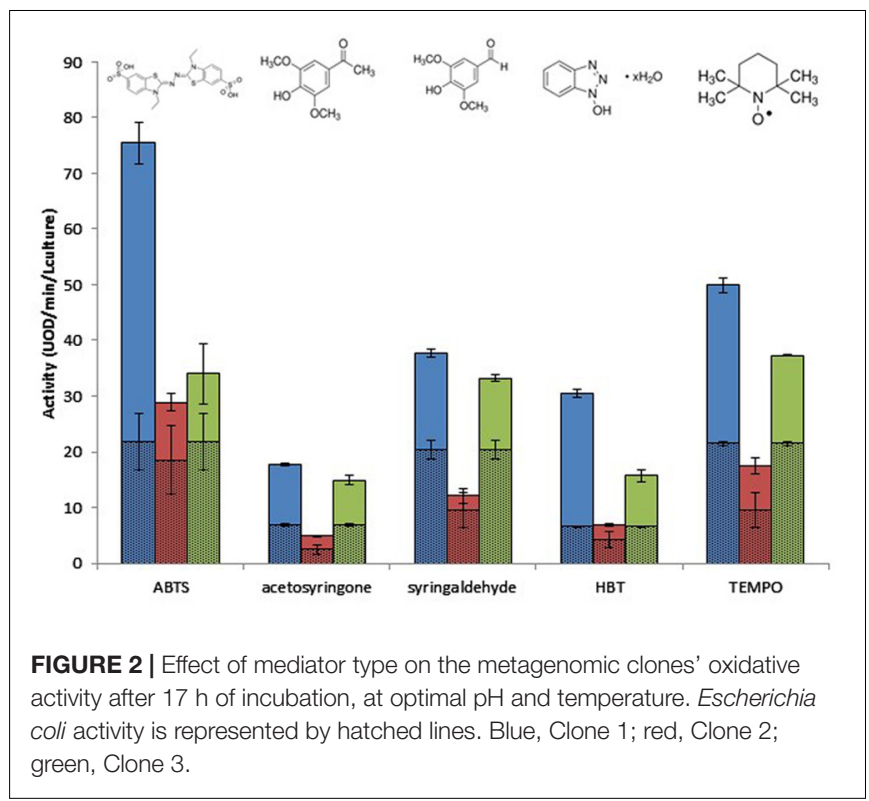

light waves from both interfaces. This principle can be exploited in order to detect the degradation of enzymatic activities by polysaccharide (Cerclier et al., 2011). However, the construction of such semi-reflective nano-layers of soluble lignin derivatives has not until now been attempted. In this study, cell extracts from the three hit clones were tested for their ability to degrade a film composed of a mix of resin and sulfonated lignin. Since the resin used to polymerize the substrate onto the layers contained aromatic molecules that could be attacked by oxidative enzymes, a film composed of a mix of resin and xyloglycan served as a control to indicate the level of resin degradation. The results are presented in Figure 3. The abiotic control represented by the reaction buffer at $\mathrm{pH} 4.5$ did not react with the polymer layers. But the biotic negative control (E. coli with an empty vector) slightly affected the color of both the sulfonated lignin/resin and the xyloglucan/resin films, with the color change suggesting a decrease in layer thickness. This may be due to a slight breaking down of the structure of the biopolymer/resin layers caused by the oxidative activity of $E$. coli previously observed on ABTS and other mediators.

The three metagenomic clones affected the color of the sulfonated lignin/resin layer to a greater extent than did the biotic negative control, with Clone 2 being the most effective. We also observed a slight alteration in the xyloglucan/resin layer caused by Clones 2 and 3 which was comparable to that observed for the control clone, suggesting that the E. coli enzymes had a slight degrading effect on the resin. In contrast, the xyloglucan/resin layer was considerably degraded by Clone 1 , suggesting that it produces activity that is able to degrade xyloglucan. Moreover, we found that no mono- or oligosaccharide was produced by Clone 1 after incubation with xyloglucan (HPAEC-PAD data analysis not presented here). We therefore put forward that Clone 1 may be affecting the xyloglucan network by altering its cohesion, as was recently shown for lytic polysaccharide monooxygenases (Villares et al., 2017).

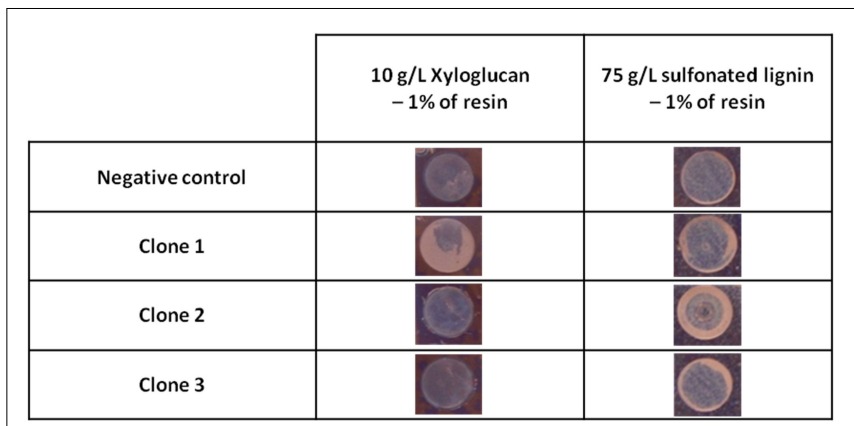

FIGURE 3 | Degradation of semi-reflective layers of xyloglucan and sulfonated lignin by the hit clones.

This new screening approach has thus allowed us to demonstrate that the enzymes produced by Clone 2 were able to depolymerize solid layers of sulfonated lignin. Once this method is optimized and automated for production in microplate format with stable sulfonated lignin layers of homogeneous thickness, it will allow large libraries to be screened for lignindepolymerization activities, at a throughput of hundreds of thousands of assays per week. This should make it possible to massively increase the rate of discovery and engineering of microbial ligninases derived from cultivated and non-cultivated bacteria and fungi.

\section{Applications in Dye Elimination}

Since the metagenomic clones displayed highly flexible specificity toward aromatic substrates, they were tested for their ability to degrade a panel of eight polycyclic aromatic dyes of diverse structures (Table 1), in order to evaluate the potential of the produced enzymes for industrial dye elimination. Five AZO dyes, one anthraquinonic, and two triphenylmethane were tested. They all contained aromatic rings with the potential for fusion, as well as various types of functional groups linked to these aromatic rings $\left(-\mathrm{OH},-\mathrm{CH}_{3},-\mathrm{NCH}_{3},-\mathrm{SO}_{3} \mathrm{H},-\mathrm{SO}_{3} \mathrm{Na}\right.$, and $\left.-\mathrm{NH}_{2}\right)$, which have been found to promote dye mineralization (Spadaro et al., 1992).

Two types of assays were performed, these being an assessment of the ability of the metagenomic clones to metabolize the targeted dyes (by monitoring their growth on a minimal medium with the dye as the sole carbon source), and dye discoloration assays in a liquid medium. Only Clone 3 was able to grow on the selective medium with the least structurally complex dye molecule on our dye list - TO - as the sole carbon source. Cytoplasmic extracts of the three clones were then incubated in liquid media containing the dyes. After reaction, the formation of solid precipitates at the bottom of wells, associated with a discoloration of the supernatant, was observed, and this was even true to a certain extent for wells containing the control clone (Figures 4, 5). Clone 1 was able to discolor all the dye solutions, while Clones 2 and 3 had a more specific effect on MG/CBR3BA/RBBR and $\mathrm{MG} / \mathrm{RB} 5 / \mathrm{CBR} 3 \mathrm{BA} / \mathrm{RBBR}$, respectively. Quantification of discoloration is frequently performed in order to assess 


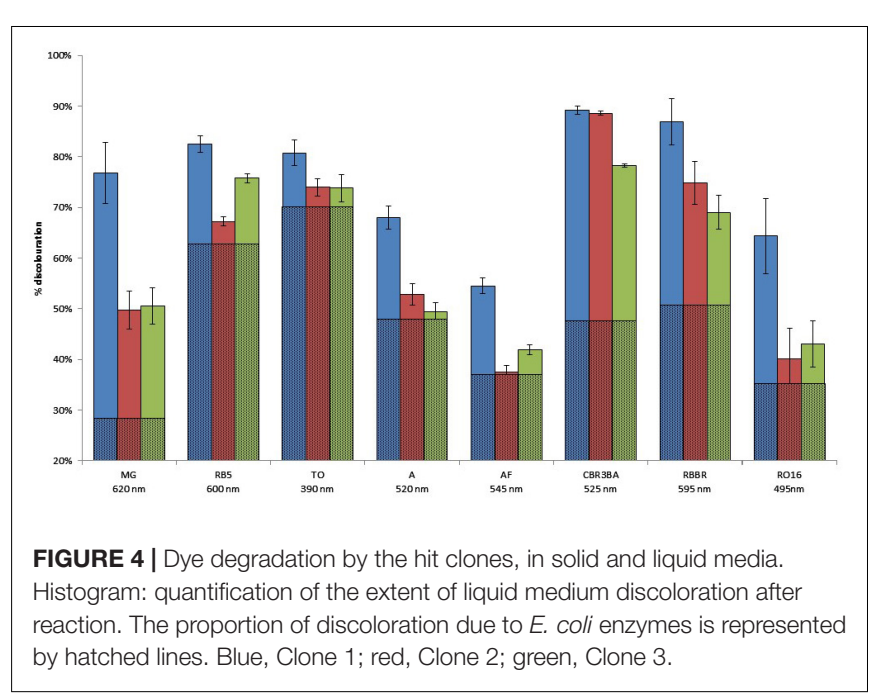

biocatalysts for dye bioremediation. Several studies have shown that aromatic compounds were either degraded or precipitated by peroxidases and polyphenol oxidases. Precipitation was attributed to the formation of phenoxy radicals followed by their spontaneous polymerization (Cooper and Nicell, 1996; Durán and Esposito, 2000; Mielgo et al., 2001; Mohan et al., 2005). Khan and Husain (2007), meanwhile, examined discoloration produced by potato and brinjal polyphenol oxidases. Dye treatment resulted in the formation of insoluble precipitates that the authors attributed to the formation of quinone-derivatives, which mediate the aggregation of aromatic pollutants. These precipitates can be easily removed from the reaction mixture by simple centrifugation, sedimentation, or filtration. Laccases also decolorize AZO dyes due to a nonspecific free radical mechanism which causes phenolic compounds to form. Their relatively low substrate specificity is associated with the use of intermediate substrates (i.e., chemical mediators) which assist in the oxidation of different substrates by facilitating electron transfer from $\mathrm{O}_{2}$ to the laccase substrate (Forootanfar et al., 2012; Si et al., 2013). They have the advantage of not requiring $\mathrm{H}_{2} \mathrm{O}_{2}$ for an oxidation reaction to be produced, as this is an expensive co-substrate (and a potential pollutant) which is considered to be responsible for dye precipitation, possibly due to free-radical formation followed by polymerization of various aromatic compounds (Bhunia et al., 2001). Few studies involving laccases have mentioned such by-products, although a study by Zille et al. (2005) did report the production due to polymerization of large numbers of coupled products, leading to a darkening of the solution. Despite the potential benefits they could bring to such depollution processes, laccases present obstacles to the biorefining of plant lignocelluloses, since they are inhibited by copper chelation caused by lignin, and also due to their double ability to depolymerize and repolymerize lignin, blocking access by cellulose- and hemicellulose-degrading enzymes to their substrates (Ruiz-Dueñas and Martínez, 2009).

Under our assay conditions, the enzymes identified as part of this study needed neither a mediator, nor the addition of copper

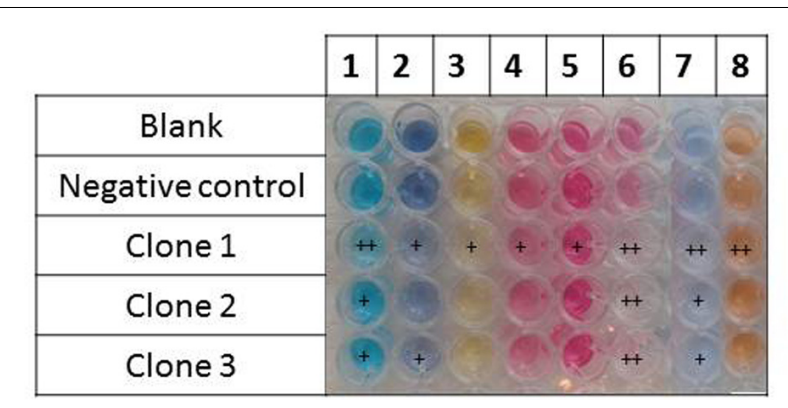

FIGURE 5 | Dye discoloration caused by the hit metagenomic clones. The picture shows the supernatants of the reaction media after reaction with the cellular extracts. 1, malachite green; 2 , reactive black 5 ; 3 , tropaeolin $0 ; 4$, amaranth; 5 , acid fuchsin; 6 , cibracon brillant red 3BA; 7 , remazol brilliant blue $\mathrm{R}$; and 8 , reactive orange 16 .

or $\mathrm{H}_{2} \mathrm{O}_{2}$, in order to be active in the culture medium. This is thus of particular interest in terms of their potential industrial applications, both in biorefining and bioremediation.

\section{Sequence Analysis}

In order to identify the genes encoding the proteins responsible for oxidative activity, the three metagenomic DNA inserts were sequenced. The reads from Clones 1,2 , and 3 were assembled into single contigs of $39.3,22.5$, and $33.7 \mathrm{~kb}$, respectively. The high sequencing depth $(100 \times)$ allowed accurate gene prediction. The number of predicted genes was 28, 18, and 29 for Clones 1, 2, and 3 , respectively.

\section{Functional Annotation}

The results of the BLASTP comparison with the NCBI_NR and Swissprot protein databases, as well as protein signature detection using InterProscan, are provided in Supplementary Table S1. Mining our metagenomic sequences for laccase encoding genes by comparing these with the LccED database did not produce significant results. This would be consistent with the fact that copper is not essential to the activity we detected for these three clones. Functional annotation allowed the identification of at least one gene for each clone that might be responsible for the activity detected (Supplementary Table S1).

In Contig 1, ORF 15, annotated as D-3-phosphoglycerate dehydrogenase $(\mathrm{PGDH})$, was the most probable target. The best BLASTP hit with proven activity was a distant D-lactate dehydrogenase from Lactobacillus pentosus (from the phylum Firmicutes; Taguchi and Ohta, 1991), which shares 29\% identity across $65 \%$ of the sequence length. The results from InterProScan confirmed this annotation, highlighting a D-isomer-specific 2hydroxyacid dehydrogenase catalytic domain, a NAD-binding domain, and an ACT C-terminal domain that is known to be related to a wide range of metabolic enzymes regulated by amino acid concentration. Other studies have already reported that dehydrogenases are involved in dye discoloration (Tilli et al., 2011). Additionally, some of them (cellobiose dehydrogenases) are redox enzymes that have an effect on the degradation of plant cell walls (Levasseur et al., 2013). In the metagenomic locus under consideration here, the dehydrogenase encoding gene is 
preceded by genes likely to constitute a functional cluster (ORFs 2-12) and which are involved in the transport, binding, and degradation of plant cell wall derived oligo- and polysaccharides. The dehydrogenase encoding gene is separated from the last CAZy encoding gene by two other ORFs coding for enzymes that could also participate in the redox process observed in this study, and which present similarities with enzymes from the L-serine biosynthesis pathway previously described in Dey et al. (2005). ORF 14, annotated as phosphoserine aminotransferase, and ORF 13, which possesses a methyltransferase tsaA-like domain, might indeed be involved in oxidative processes brought about by the removal of methyl groups. Indeed, like dehydrogenases, it has been shown that methyltransferases are involved in some of the degradation of lignin derivatives by fungi and bacteria (Jeffers et al., 1997; Masai et al., 2007).

In Contig 2, a cluster of three genes (ORFs 15, 16, and 17 annotated to code for a methionine synthase, a methyltransferase, and a metallo-dependent hydrolase) was proposed to code for the proteins responsible for the redox activity. ORFs 15 and 17 did not present any significant similarity with biochemically characterized proteins. The BLAST hit for the ORF 16 product which was the best characterized was the cobalamin-dependent methionine synthase $(\mathrm{MetH})$ from Thermotoga maritima, with $66 \%$ query coverage, $36 \%$ identity, and an $e$-value of $2 e-92$. B12-dependent MetH is a large modular enzyme that uses the cobalamin cofactor as a methyl donor or acceptor in methyl transfer reactions (Evans et al., 2004). This enzyme was proposed to catalyze the conversion of 5-methyltetrahydrofolate and L-homocysteine to tetrahydrofolate and L-methionine in the final step of de novo methionine biosynthesis. It requires methylcobalamin as a cofactor. In addition, ORF 17 presents an amidohydrolase domain. Amidohydrolases are known to be involved in a variety of trans-methylations and rearrangement reactions for the transport and metabolism of amino acids, particularly methionine, where cobalamin and methyl-cobalamin are used as cofactors (Rodionov, 2003). It thus seems that the gene cluster evidenced in Clone 2 could be a new pathway of L-methionine biosynthesis. The redox activities we observed could be due to the fact that L-methionine is an essential amino acid required for a large number of important cellular functions, including the methylation of aromatic compounds by methyltransferases (Jeffers et al., 1997; Rodionov, 2004; Masai et al., 2007).

The Contig 3 sequence is particularly rich in gene coding for oxidizing enzymes. The contig contains a gene cluster organized as previously described in a study on the catabolism of phenolic compounds by facultative anaerobe bacteria (Carmona and Díaz, 2005). In these bacteria, the degradation of the phenolic substrate is caused by its reduction to a nonaromatic compound by a heterotetrameric reductase. In Contig 3 , ORFs $6,7,8$, and 9 were annotated as the $\delta \alpha \beta \gamma$ subunits of a 2-oxoglutarate ferredoxin oxidoreductase. The BLASTP hits which were best characterized were the subunits of a distant 2-oxoisovalerate oxidoreductase functionally associated with amino acid catabolism (Heider et al., 1996; Tersteegen et al., 1997). The domains predicted using InterProScan assigned the $\delta$ - and $\beta$-subunits to $4 \mathrm{Fe}-4 \mathrm{~S}$ ferredoxin iron-sulfur and thiamine-diphosphate-binding domains, respectively. The $\alpha$ - and $\gamma$-subunits carried signatures of the catalytic domains of a pyruvate flavodoxin/ferredoxin oxidoreductase and a pyruvate/ketoisovalerate oxidoreductase, respectively. This complex acts on the aldehyde or oxo group of donors with ferredoxin as an acceptor and coenzyme A. It has been previously proposed that the reaction that produces reduced ferredoxin also produces a reduction in aromatic rings (Boll et al., 2002; Dorner and Boll, 2002), which would explain the phenotypes observed in this study. In addition, in Contig 3, the oxidoreductase-encoding genes were close to a gene encoding a putative transporter (ORF 2) specific to a redox cofactor, i.e., riboflavin. Other genes encoding redox proteins were found on the opposite strand of the contig. They belong to a cluster of nine genes (ORFs 11-19) of which six (ORFs 14-19) are annotated as the RnfBAEDC complex. Biegel et al. (2011) have published an extensive review of structurally equivalent complexes. These are membranebound electron/ion transport systems occasionally associated with cytochrome $\mathrm{C}$, as would also seem to be the case with this cluster (ORFs 11 and 12), and have been found to be involved in the respiratory chain. The Rnf complex/cytochrome $\mathrm{C}$ association was previously shown to be co-expressed in Methanosarcina acetivorans ( $\mathrm{Li}$ et al., 2006). These complexes are present in a wide variety of prokaryotes and are functionally assigned as NADH-oxidoreductase. The Rfn couples the flow of electrons from the reduced ferredoxin to NAD+ thereby generating a sodium ion gradient across the cytoplasmic membrane. In the Acetobacterium woodii strain, the Rnf complex is involved in the reduction of caffeate, $p$-coumarate, and ferulate, three widespread components of soil deriving from the degradation of lignin (Müller et al., 2008). Consequently, the phenotypes found in this study are the product of the involvement of multiprotein complexes that could not have been retrieved from short metagenomic DNA fragments. In addition, these multi-enzymatic systems ensure cascades of redox reactions, which most likely also involve $E$. coli cellular metabolites.

\section{Taxonomic Assignment and Sequence Prevalence in the Bovine Rumen Microbiome}

It was impossible to accurately assign the three metagenomic inserts from a taxonomical point of view, as their sequences were too distant from any available sequenced genome. A MEGAN analysis using low stringent criteria revealed that the sequences were probably derived from Firmicute bacteria. Indeed, 6/28, 9/18, and 5/29 ORF sequences from Clones 1, 2, and 3, respectively, were assigned to the phylum Firmicutes. It should be noted that the vast majority of ORFs from Contigs 1 and 3 (22 and 23 ORFs, respectively) were assigned to bacteria from environmental samples without any further taxonomic information other than the fact that they showed high identity to segments of two fosmid sequences from the rumen metagenome of two Jersey cows in a study by Wang et al. (2013) which involved activity-based screening of polysaccharide degradation. Contig 1 had 59\% sequence coverage and 90\% identity with Contig 33 from the study by Wang et al. (2013), while Contig 3 from our study 
showed $60 \%$ sequence coverage and $87 \%$ identity with Contig 1549a. Contigs 33 and 1549a were assigned to the phylum Firmicutes. They were retrieved from metagenomic clones active on plant cell wall polysaccharides They contained CAZyencoding genes similar to the GH10- and GH94-encoding genes found in our Contigs 1 (ORFs 11 and 12) and 3 (ORF 28). It is interesting to note that such gene clusters were retrieved both in the course of the screening of polysaccharide degrading enzymes (Wang et al., 2013) and, in the present study, redox enzymes acting on lignin derivatives. This constitutes the first piece of evidence that bacterial putative ligninases and CAZymes can be encoded by the same genomic loci, dedicated to the degradation of walls of plant cells.

\section{CONCLUSION}

In this study, functional metagenomics was used to discover new redox enzymes and metabolic pathways from the bovine rumen microbiome, active on various aromatic substrates derived from textile dyeing and the chemical treatment of lignocelluloses in the pulp and paper industries. None of these enzymes require the addition of metals or mediators to the reaction media, giving them a particular advantage over the laccases and peroxidases that are the main enzymes currently used in biorefining and dye bioremediation. Sequence analysis revealed that each of the contigs contained several redox enzymes of different functional and structural families, which probably work in synergy to degrade and metabolize the targeted substrates. In Contigs 1 and 2, the target enzymes were related to amino acid metabolism. Sequence analysis also suggested that the redox enzymes produced by the clones and identified in this study would not require the supply of oxygen. Their electron acceptors/donors would instead be, for instance, ions, cobalamin, or $\mathrm{NAD}(\mathrm{P})$, which are synthetized or absorbed in the host strain cytoplasm. Microbial processes using recombinant bacteria able to produce the entire pathways discovered here would thus be more appropriate than enzyme-based processes, which would require the addition of cofactors. In addition, two of the genomic loci discovered in this study harbor genes that encode both redox enzymes capable of acting on lignin derivatives and hemicellulases, suggesting that these bacterial enzymes could act synergistically to break down the plant cell wall network. Nevertheless, in order to accurately identify the functions of the different enzymes encoded on these loci, transcriptomic analysis and rational truncation of the fosmid inserts will be required, as well as an in-depth structural characterization of the products released from a simple model substrate. Finally, their suitability for use in biorefineries will have to be established by testing these

\section{REFERENCES}

Abrão, F. O., Duarte, E. R., Pessoa, M. S., Santos, V. L. D., Freitas Júnior, L. F., Barros, K. O., et al. (2017). Notable fibrolytic enzyme production by Aspergillus spp. isolates from the gastrointestinal tract of beef cattle fed in lignified pastures. PLoS One 12:e0183628. doi: 10.1371/journal.pone. 0183628 clones on native lignin matrixes, and the way they function on this kind of substrate will also need to be studied further.

The datasets generated in the course of this study are available in the repository of the DDBJ/EMBL/GenBank Nucleotide Sequence Database under accession numbers LT674548, LT674549, LT674550 .

\section{AUTHOR CONTRIBUTIONS}

LU: acquisition, analysis, interpretation of data, and drafting the work. GP-V: conception, design of the work, analysis, interpretation of data, and drafting the work. DC, DM, BC, CM, PR: conception and design of the work and drafting. AST: design, realization, analysis, and drafting of HPLC experiment. $\mathrm{AR}, \mathrm{CK}$, and MC: acquisition, analysis of the data, and drafting. EL: conception, design of the work, data acquisition, analysis, interpretation of data, and drafting the work.

\section{FUNDING}

This research was funded by the French Ministry of Education and Research (Ministère de l'Enseignement Supérieur et de la Recherche), the INRA metaprogramme M2E (project Metascreen), the French National Research Agency (project REFLEX, grant number ANR 2011 NANO 007 03), and the European Union's framework programme Horizon 2020 (H2020BBI-PPP-2015-720303, Zelcor).

\section{ACKNOWLEDGMENTS}

We would like to cordially thank Nadège Beury, Emilie Amblard, and Zhi Wang for their technical assistance. The high-throughput screening work was carried out at the Laboratory for BioSystems and Process Engineering (Toulouse, France) using tools provided by ICEO, a service dedicated to the screening and discovery of new enzymes. ICEO was supported by grants from the Région Midi-Pyrénées, the European Regional Development Fund, and the Institut National de la Recherche Agronomique (INRA).

\section{SUPPLEMENTARY MATERIAL}

The Supplementary Material for this article can be found online at: https://www.frontiersin.org/articles/10.3389/fmicb. 2018.00861/full\#supplementary-material

\footnotetext{
${ }^{4}$ https://www.ncbi.nlm.nih.gov/genbank/
} et al. (2017). The first acidobacterial laccase-like multicopper oxidase revealed by metagenomics shows high salt and thermo-tolerance. Appl. Microbiol. Biotechnol. 101, 6261-6276. doi: 10.1007/s00253-017-8345-y

Ausec, L., Zakrzewski, M., Goesmann, A., Schlüter, A., and Mandic-Mulec, I. (2011). Bioinformatic analysis reveals high diversity of bacterial genes for laccase-like enzymes. PLoS One 6:e25724. doi: 10.1371/journal.pone.0025724 
Baba, Y., Matsuki, Y., Mori, Y., Suyama, Y., Tada, C., Fukuda, Y., et al. (2017). Pretreatment of lignocellulosic biomass by cattle rumen fluid for methane production: bacterial flora and enzyme activity analysis. J. Biosci. Bioeng. 123, 489-496. doi: 10.1016/j.jbiosc.2016.11.008

Beloqui, A., Pita, M., Polaina, J., Martinez-Arias, A., Golyshina, O. V., Zumarraga, M., et al. (2006). Novel polyphenol oxidase mined from a metagenome expression library of bovine rumen: biochemical properties, structural analysis, and phylogenetic relationships BIOCHEMICAL PROPERTIES, STRUCTURAL ANALYSIS, AND PHYLOGENETIC RELATIONSHIPS. J. Biol. Chem. 281, 22933-22942. doi: 10.1074/jbc. M600577200

Bhunia, A., Durani, S., and Wangikar, P. P. (2001). Horseradish peroxidase catalyzed degradation of industrially important dyes. Biotechnol. Bioeng. 72, 562-567. doi: 10.1002/1097-0290(20010305)72:5<562::AID-BIT1020>3.0. $\mathrm{CO} ; 2-\mathrm{S}$

Biegel, E., Schmidt, S., González, J. M., and Müller, V. (2011). Biochemistry, evolution and physiological function of the Rnf complex, a novel ion-motive electron transport complex in prokaryotes. Cell. Mol. Life Sci. 68, 613-634. doi: 10.1007/s00018-010-0555-8

Boll, M., Fuchs, G., and Heider, J. (2002). Anaerobic oxidation of aromatic compounds and hydrocarbons. Curr. Opin. Chem. Biol. 6, 604-611. doi: 10.1016/S1367-5931(02)00375-7

Brown, M. E., and Chang, M. C. (2014). Exploring bacterial lignin degradation. Curr. Opin. Chem. Biol. 19, 1-7. doi: 10.1016/j.cbpa.2013.11.015

Camarero, S., Ibarra, D., Martinez, M. J., and Martinez, A. T. (2005). LigninDerived compounds as efficient laccase mediators for decolorization of different types of recalcitrant dyes. Appl. Environ. Microbiol. 71, 1775-1784. doi: 10.1128/ AEM.71.4.1775-1784.2005

Carmona, M., and Díaz, E. (2005). Iron-reducing bacteria unravel novel strategies for the anaerobic catabolism of aromatic compounds: anaerobic benzoate degradation. Mol. Microbiol. 58, 1210-1215. doi: 10.1111/j.1365-2958.2005. 04937.x

Cerclier, C., Guyomard-Lack, A., Moreau, C., Cousin, F., Beury, N., Bonnin, E., et al. (2011). Coloured semi-reflective thin films for biomass-hydrolyzing enzyme detection. Adv. Mater. 23, 3791-3795. doi: 10.1002/adma.2011 01971

Cooper, V. A., and Nicell, J. A. (1996). Removal of phenols from a foundry wastewater using horseradish peroxidase. Water Res. 30, 954-964. doi: 10.1016/ 0043-1354(95)00237-5

Courtois, S., Cappellano, C. M., Ball, M., Francou, F. X., Normand, P., Helynck, G., et al. (2003). Recombinant environmental libraries provide access to microbial diversity for drug discovery from natural products. Appl. Environ. Microbiol. 69, 49-55. doi: 10.1128/AEM.69.1.49-55.2003

de Vasconcellos, S. P., Angolini, C. F. F., García, I. N. S., Martins Dellagnezze, B., da Silva, C. C., Marsaioli, A. J., et al. (2010). Screening for hydrocarbon biodegraders in a metagenomic clone library derived from Brazilian petroleum reservoirs. Org. Geochem. 41, 675-681. doi: 10.1016/j.orggeochem.2010.03.014

Dey, S., Hu, Z., Xu, X. L., Sacchettini, J. C., and Grant, G. A. (2005). D-3Phosphoglycerate dehydrogenase from mycobacterium tuberculosis is a link between the Escherichia coli and mammalian enzymes. J. Biol. Chem. 280, 14884-14891. doi: 10.1074/jbc.M414488200

Diaz, E., Ferrandez, A., Prieto, M. A., and Garcia, J. L. (2001). Biodegradation of aromatic compounds by Escherichia coli. Microbiol. Mol. Biol. Rev. 65, 523-569. doi: 10.1128/MMBR.65.4.523-569.2001

Dorner, E., and Boll, M. (2002). Properties of 2-oxoglutarate:ferredoxin oxidoreductase from thauera aromatica and its role in enzymatic reduction of the aromatic ring. J. Bacteriol. 184, 3975-3983. doi: 10.1128/JB.184.14.39753983.2002

Durán, N., and Esposito, E. (2000). Potential applications of oxidative enzymes and phenoloxidase-like compounds in wastewater and soil treatment: a review. Appl. Catal. B Environ. 28, 83-99. doi: 10.1016/S0926-3373(00)00168-5

Evans, J. C., Huddler, D. P., Hilgers, M. T., Romanchuk, G., Matthews, R. G., and Ludwig, M. L. (2004). Structures of the N-terminal modules imply large domain motions during catalysis by methionine synthase. Proc. Natl. Acad. Sci. U.S.A. 101, 3729-3736. doi: 10.1073/pnas.0308082100

Ferrer, M., Golyshina, O. V., Chernikova, T. N., Khachane, A. N., Reyes-Duarte, D., Santos, V. A., et al. (2005). Novel hydrolase diversity retrieved from a metagenome library of bovine rumen microflora: enzymatic diversity from bovine rumen metagenome. Environ. Microbiol. 7, 1996-2010. doi: 10.1111/j. 1462-2920.2005.00920.x

Forootanfar, H., Moezzi, A., Aghaie-Khozani, M., Mahmoudjanlou, Y., Ameri, A., Niknejad, F., et al. (2012). Synthetic dye decolorization by three sources of fungal laccase. Iran. J. Environ. Health Sci. Eng. 9:27. doi: 10.1186/1735-2746-927

Heider, J., Mai, X., and Adams, M. W. (1996). Characterization of 2ketoisovalerate ferredoxin oxidoreductase, a new and reversible coenzyme A-dependent enzyme involved in peptide fermentation by hyperthermophilic archaea. J. Bacteriol. 178, 780-787. doi: 10.1128/jb.178.3.780-787. 1996

Huson, D. H., Mitra, S., Ruscheweyh, H.-J., Weber, N., and Schuster, S. C. (2011). Integrative analysis of environmental sequences using MEGAN4. Genome Res. 21, 1552-1560. doi: 10.1101/gr.120618.111

Jeffers, M. R., McRoberts, W. C., and Harper, D. B. (1997). Identification of a phenolic 3-O-methyltransferase in the lignin-degrading fungus Phanerochaete chrysosporium. Microbiology 143, 1975-1981. doi: 10.1099/00221287-143-61975

Jones, P., Binns, D., Chang, H.-Y., Fraser, M., Li, W., McAnulla, C., et al. (2014). InterProScan 5: genome-scale protein function classification. Bioinformatics 30, 1236-1240. doi: 10.1093/bioinformatics/btu031

Khan, A. A., and Husain, Q. (2007). Potential of plant polyphenol oxidases in the decolorization and removal of textile and non-textile dyes. J. Environ. Sci. China 19, 396-402. doi: 10.1016/S1001-0742(07)60066-7

Lebo, S. E., Gargulak, J. D., and McNally, T. J. (2001). "Lignin," in KirkOthmer Encyclopedia of Chemical Technology, ed. Kirk-Othmer (Hoboken, NJ: John Wiley \& Sons, Inc). doi: 10.1002/0471238961.12090714120914.a01. pub2

Levasseur, A., Drula, E., Lombard, V., Coutinho, P. M., and Henrissat, B. (2013). Expansion of the enzymatic repertoire of the CAZy database to integrate auxiliary redox enzymes. Biotechnol. Biofuels 6, 1-14. doi: 10.1186/1754-68346-41

Li, Q., Li, L., Rejtar, T., Lessner, D. J., Karger, B. L., and Ferry, J. G. (2006). Electron transport in the pathway of acetate conversion to methane in the marine archaeon Methanosarcina acetivorans. J. Bacteriol. 188, 702-710. doi: 10.1128/JB.188.2.702-710.2006

Masai, E., Katayama, Y., and Fukuda, M. (2007). Genetic and biochemical investigations on bacterial catabolic pathways for lignin-derived aromatic compounds. Biosci. Biotechnol. Biochem. 71, 1-15. doi: 10.1271/bbb. 60437

Mielgo, I., Moreira, M., Feijoo, G., and Lema, J. (2001). A packed-bed fungal bioreactor for the continuous decolourisation of azo-dyes (Orange II). J. Biotechnol. 89, 99-106. doi: 10.1016/S0168-1656(01)00319-4

Mohan, S. V., Prasad, K. K., Rao, N. C., and Sarma, P. N. (2005). Acid azo dye degradation by free and immobilized horseradish peroxidase (HRP) catalyzed process. Chemosphere 58, 1097-1105. doi: 10.1016/j.chemosphere.2004.09.070

Morozova, O. V., Shumakovich, G. P., Shleev, S. V., and Yaropolov, Y. I. (2007). Laccase-mediator systems and their applications: a review. Appl. Biochem. Microbiol. 43, 523-535. doi: 10.1134/S00036838070 50055

Müller, V., Imkamp, F., Biegel, E., Schmidt, S., and Dilling, S. (2008). Discovery of a ferredoxin:NAD+-oxidoreductase (Rnf) in Acetobacterium woodii: a novel potential coupling site in acetogens. Ann. N. Y. Acad. Sci. 1125, 137-146. doi: 10.1196/annals.1419.011

Noguchi, H., Park, J., and Takagi, T. (2006). MetaGene: prokaryotic gene finding from environmental genome shotgun sequences. Nucleic Acids Res. 34, 5623-5630. doi: 10.1093/nar/gkl723

Pardo, I., Chanagá, X., Vicente, A., Alcalde, M., and Camarero, S. (2013). New colorimetric screening assays for the directed evolution of fungal laccases to improve the conversion of plant biomass. BMC Biotechnol. 13:90. doi: 10.1186/ 1472-6750-13-90

Phugare, S. S., Kalyani, D. C., Surwase, S. N., and Jadhav, J. P. (2011). Ecofriendly degradation, decolorization and detoxification of textile effluent by a developed bacterial consortium. Ecotoxicol. Environ. Saf. 74, 1288-1296. doi: 10.1016/j. ecoenv.2011.03.003

Pieper, D. H., Martins dos Santos, V. A., and Golyshin, P. N. (2004). Genomic and mechanistic insights into the biodegradation of organic pollutants. Curr. Opin. Biotechnol. 15, 215-224. doi: 10.1016/j.copbio.2004.03.008 
Raj, A., Reddy, M. M., Chandra, R., Purohit, H. J., and Kapley, A. (2007). Biodegradation of kraft-lignin by Bacillus sp. isolated from sludge of pulp and paper mill. Biodegradation 18, 783-792. doi: 10.1007/s10532-0079107-9

Rodionov, D. A. (2003). Comparative Genomics of the Vitamin B12 metabolism and regulation in prokaryotes. J. Biol. Chem. 278, 41148-41159. doi: 10.1074/ jbc.M305837200

Rodionov, D. A. (2004). Comparative genomics of the methionine metabolism in Gram-positive bacteria: a variety of regulatory systems. Nucleic Acids Res. 32, 3340-3353. doi: 10.1093/nar/gkh659

Ruiz-Dueñas, F. J., and Martínez, Á. T. (2009). Microbial degradation of lignin: how a bulky recalcitrant polymer is efficiently recycled in nature and how we can take advantage of this. Microb. Biotechnol. 2, 164-177. doi: 10.1111/j.17517915.2008.00078.x

Si, J., Peng, F., and Cui, B. (2013). Purification, biochemical characterization and dye decolorization capacity of an alkali-resistant and metal-tolerant laccase from Trametes pubescens. Bioresour. Technol. 128, 49-57. doi: 10.1016/j. biortech.2012.10.085

Silva, C. C., Hayden, H., Sawbridge, T., Mele, P., De Paula, S. O., Silva, L. C., et al. (2013). Identification of genes and pathways related to phenol degradation in metagenomic libraries from petroleum refinery wastewater. PLoS One 8:e61811. doi: 10.1371/journal.pone.0061811

Sirim, D., Wagner, F., Wang, L., Schmid, R. D., and Pleiss, J. (2011). The laccase engineering database: a classification and analysis system for laccases and related multicopper oxidases. Database 2011:bar006. doi: 10.1093/database/ bar006

Solís, M., Solís, A., Pérez, H. I., Manjarrez, N., and Flores, M. (2012). Microbial decolouration of azo dyes: a review. Process Biochem. 47, 1723-1748. doi: 10.1016/j.procbio.2012.08.014

Spadaro, J. T., Gold, M. H., and Renganathan, V. (1992). Degradation of azo dyes by the lignin-degrading fungus Phanerochaete chrysosporium. Appl. Environ. Microbiol. 58, 2397-2401.

Strachan, C. R., Singh, R., VanInsberghe, D., Ievdokymenko, K., Budwill, K., Mohn, W. W., et al. (2014). Metagenomic scaffolds enable combinatorial lignin transformation. Proc. Natl. Acad. Sci. U.S.A. 111, 10143-10148. doi: 10.1073/ pnas. 1401631111

Suenaga, H., Ohnuki, T., and Miyazaki, K. (2007). Functional screening of a metagenomic library for genes involved in microbial degradation of aromatic compounds. Environ. Microbiol. 9, 2289-2297. doi: 10.1111/j.1462-2920.2007. 01342.x

Taguchi, H., and Ohta, T. (1991). D-lactate dehydrogenase is a member of the D-isomer-specific 2-hydroxyacid dehydrogenase family. Cloning, sequencing, and expression in Escherichia coli of the D-lactate dehydrogenase gene of Lactobacillus plantarum. J. Biol. Chem. 266, 12588-12594.

Tasse, L., Bercovici, J., Pizzut-Serin, S., Robe, P., Tap, J., Klopp, C., et al. (2010). Functional metagenomics to mine the human gut microbiome for dietary fiber catabolic enzymes. Genome Res. 20, 1605-1612. doi: 10.1101/gr. 108332.110
Tavares, A. P., Cristóvão, R. O., Loureiro, J. M., Boaventura, R. A., and Macedo, E. A. (2008). Optimisation of reactive textile dyes degradation by laccasemediator system. J. Chem. Technol. Biotechnol. 83, 1609-1615. doi: 10.1002/jctb. 1952

Tersteegen, A., Linder, D., Thauer, R. K., and Hedderich, R. (1997). Structures and functions of four anabolic 2-oxoacid oxidoreductases in Methanobacterium thermoautotrophicum. Eur. J. Biochem. FEBS 244, 862-868. doi: 10.1111/j.14321033.1997.00862.x

Tilli, S., Ciullini, I., Scozzafava, A., and Briganti, F. (2011). Differential decolorization of textile dyes in mixtures and the joint effect of laccase and cellobiose dehydrogenase activities present in extracellular extracts from Funalia trogii. Enzyme Microb. Technol. 49, 465-471. doi: 10.1016/j.enzmictec. 2011.08.002

Torres-Duarte, C., Roman, R., Tinoco, R., and Vazquez-Duhalt, R. (2009). Halogenated pesticide transformation by a laccase-mediator system. Chemosphere 77, 687-692. doi: 10.1016/j.chemosphere.2009.07.039

Ufarté, L., Laville, É., Duquesne, S., and Potocki-Veronese, G. (2015). Metagenomics for the discovery of pollutant degrading enzymes. Biotechnol. Adv. 33, 1845-1854. doi: 10.1016/j.biotechadv.2015. 10.009

Villares, A., Moreau, C., Bennati-Granier, C., Garajova, S., Foucat, L., Falourd, X., et al. (2017). Lytic polysaccharide monooxygenases disrupt the cellulose fibers structure. Sci. Rep. 7:40262. doi: 10.1038/srep40262

Wang, L., Hatem, A., Catalyurek, U. V., Morrison, M., and Yu, Z. (2013). Metagenomic insights into the carbohydrate-active enzymes carried by the microorganisms adhering to solid digesta in the rumen of cows. PLoS One 8:e78507. doi: 10.1371/journal.pone.0078507

Ye, M., Li, G., Liang, W. Q., and Liu, Y. H. (2010). Molecular cloning and characterization of a novel metagenome-derived multicopper oxidase with alkaline laccase activity and highly soluble expression. Appl. Microbiol. Biotechnol. 87, 1023-1031. doi: 10.1007/s00253-010-2507-5

Zille, A., Gornacka, B., Rehorek, A., and Cavaco-Paulo, A. (2005). Degradation of Azo dyes by Trametes villosa laccase over long periods of oxidative conditions. Appl. Environ. Microbiol. 71, 6711-6718. doi: 10.1128/AEM.71.11.6711-6718. 2005

Conflict of Interest Statement: The authors declare that the research was conducted in the absence of any commercial or financial relationships that could be construed as a potential conflict of interest.

Copyright (c) 2018 Ufarté, Potocki-Veronese, Cecchini, Tauzin, Rizzo, Morgavi, Cathala, Moreau, Cleret, Robe, Klopp and Laville. This is an open-access article distributed under the terms of the Creative Commons Attribution License (CC BY). The use, distribution or reproduction in other forums is permitted, provided the original author(s) and the copyright owner are credited and that the original publication in this journal is cited, in accordance with accepted academic practice. No use, distribution or reproduction is permitted which does not comply with these terms. 